\title{
Indian Art and European Science: Patnakalam and Colonial Botanical Drawings
}

\author{
Saumya Garima Jaipuriar \\ Assistant Professor, Department of English, Kirorimal College, University of Delhi. \\ ORCID: oooo-0oo2-4336-6278Email: sgjaipuriar@gmail.com,
}

\begin{abstract}
This paper seeks to explore how scientific documentation fuelled by Enlightenment and indigenous art intermingled to create Patnakalam in nineteenth century India. Patnakalam, a school of painting that flourished in Patna, Bihar in the nineteenth and early twentieth centuries, came into existence with the complex interactions between an indigenous artistic tradition and a western visual sensibility mediated by the requirements of science. Botanists of the East India Company employed native artists to make illustrations of local plant species in an attempt to scientifically catalogue all of the natural resources of the region. This inevitably contributed to the formation of a style of painting which went on to have an enduring legacy far beyond their taxonomical albums.
\end{abstract}

Keywords: Company Painting, Patnakalam, Modern Indian Art, Indian Art History, British Colonial History, Age of Enlightenment

\section{Introduction}

Colonialism in the age of Enlightenment provided great new spaces for intellectual explorations. East India Company with its factories in Masulipatnam (established in 1611), Surat (1612), Madras (1640), Bombay (1668) and Calcutta (1690) had operated as a trading company in India for over a century before Enlightenment. What changed significantly by the age of Enlightenment was the accelerated pace of colonial expansion and consolidation of territories. The Battle of Plassey (1757) between the Company and the Nawab of Bengal and his French allies along with the end of the Seven Years' War between Britain and France (1763) set the stage for rapid and aggressive colonization in India. While the ideas of Enlightenment flourished in Europe, the East India Company transformed from a trading enterprise into a colonizing agent serving the interests of British imperialism in the Indian sub-continent.

In Emmanuel Kant's writing, Enlightenment thought hinged on the "freedom to make public use of one's reason in all matters" (1999 [1784], p. 18). However, its manifestation in colonial spaces was through the historical fact of imperialism. In the age of Enlightenment, the general fascination with the exotic turned into a systematic and potentially exhaustive empiricist gathering of knowledge. It fuelled the commissioning and compilation of statistical, geological and archaeological surveys of colonial territories as the East Company India consolidated their power in the Indian subcontinent by the end of

(c) AesthetixMS 2020. This Open Access article is published under a Creative Commons Attribution Non-Commercial 4.0 International License (http://creativecommons.org/licenses/by-nc/4.o/), which permits non-commercial re-use, distribution, and reproduction in any medium, provided the original work is properly cited. For citation use the DOI. For commercial re-use, please contact editor@rupkatha.com. 
the eighteenth century. It also manifested in the art that European patrons commissioned from Indian artists for various purposes. This in turn led to the development of Indowestern hybrid styles of painting. Patnakalam School of art was one such style.

\section{Science in Europe: Linnaean Taxonomy}

Developments in the sciences in Europe in the eighteenth century had profound consequences on artistic production in India. Early Patnakalam paintings include images of flowers that combine both the delicacy of indigenous styles like the Mughal School and the accuracy of representation governed by new ideas in taxonomy in Europe. Arguably, the beginning of the development of a distinct Patnakalam idiom was a directly informed by European natural history illustration canon. For a better understanding of how scientific accuracy came to have a bearing on decorative art in Colonial India, a historical survey of the rise of modern taxonomy and botanical illustrations in eighteenth century Europe is in order.

The Age of Enlightenment saw great leaps in scientific thought in Europe. Even though the scientific disciplines as we understand them did not fully develop until the late nineteenth century, the seeds of modern ways of looking at the world could be seen in the developments and methodologies of eighteenth century sciences. The field of natural history - a discipline that encompassed botany, zoology, meteorology, and geology developed more and more as a science of forms and categories with its increasing focus on description and crucially, classification of all forms of nature. According to Thomas L Hankins, natural history in the age of Enlightenment relied on careful observation of natural phenomena rather than the Cartesian model of deductive reasoning on abstract principle, as the way to effectively know the world (1985, p. 119).

Even though the drive to effectively understand natural phenomena spurred scientific thought, this was not in any way a secularized pursuit. On the contrary, the search for a natural system for classification of all nature was a search to understand the grand design of God. It is this search for the truest system of classification that gave rise to many interesting debates in the field of Botany about the essential characteristics or 'essence' of plants.

One of the most important contributors into these debates was Carl Linnaeus (17071778) whose taxonomical system of binomial nomenclature continues to have an enduring legacy in Botany and Zoology. He published Philosophia Botanica in 1751. The publication of his magnum opus Species Plantarum in 1753 is considered the starting point of modern taxonomy. In it he described a large number of plant species using his system of binomial nomenclature based on their sexual characteristics. The Linnaean classification system became almost universalized during his lifetime. He died in 1778. Ten years later, the Linnaean Society of London was founded after his natural history collection and letters were acquired by English Botanist James Edward Smith.

Carl Linnaeus built on the works of botanists like John Ray (1627-1705), Joseph Pitton de Tournefort and Herman Boerhaave (1668-1638). He came up with a system of 
classification for the identification of flora that not only accommodated all known species but also allowed for the placement of unknown, hitherto undocumented, exotic plants and trees. He based his system of classification on the sexual organ of the plant, "fruit-body" which he described in great detail through aphorisms in Philosophia Botanica. The fruitbody consists of the flower and the fruit of the plant. His system has five ranks: class, order, genera, species and variety. According to this system, all species with similarly constructed fruit-bodies belong to one genus. He also devised binomial nomenclature - a naming system that called every plant by its genus and species.

212. In the verbal description of a vegetable, all the names are either silent, as those of the class and the order; or enunciated, as those of the genus, species, and variety. Every plant-name must consist of a generic name and a specific one. The names of the class and the order must never be included in the name of the plant, but should be supplied by the understanding... (2003 [1751], p. 170)

This was a big improvement on already existing taxonomical styles. Instead of including long descriptions in the name - like the phrase-names of older systemetists - it allowed for a manageably learnable template that could be easily used by amateurs as well as professionals.

The impact of the Linnaeus's sexual binomial nomenclature was immense. In an era of geographical exploration, his pupils travelled far and wide to collect and document exotic flora. In Britain leading Botanists of the time such as Philip Miller (1691-1771), John Hill (1716-1775) and William Hudson (1730-1793) adopted his system in their work. By the early 1760s, the Linnaean system became a fixture of the British taxonomic establishment (Stafleu, 1971, p. 203). There was a renewed interest in Botany at home as new species made their way to Britain at an unprecedented rate. In addition to that, the rapidly growing empire became the arena for the realization of the unmet potential of Linnaean taxonomy.

The establishment of the Linnean Society of London in 1788 and its continued prestige in subsequent decades cemented Linnaeus's scientific stature and validated his system. Many of its members including William Roxburgh (1751-1815), Nathaniel Wallich (1786-1854) and Francis Hamilton-Buchanan were colonial administrators who actively participated in the formation of knowledge about Indian flora and fauna. Roxburgh served in Madras Presidency and later Bengal where he headed the Calcutta Botanical gardens. His most notable achievement was the catalogue of the Calcutta Botanical gardens, Hortus Bengalensis. Wallich prepared an extensive herbarium and catalogued close to 20,000 plant species. He also got numerous Botanical illustrations made by indigenous artists. The Wallich catalogue, housed at the Royal Botanical Garden, Edinburgh continues to be an invaluable database in taxonomical research. All these men, and many more like them, were Linnaean "Evangelists". They took his system far and wide and in some cases helped produce extraordinary cultural documents.

Linnaeus's system transformed the art of Botanical illustration in Europe. The Linnaean method is designed to provide a very detailed description of a given specimen. It does not require visual guides to identify a species. Yet his books contained images and he acknowledged the work of botanical illustrators. Given the robust pre-existing tradition of 
botanical illustration in Europe it was conceptually impossible to imagine a complete system regarding classification of flora without supplementing it with a visual guide. So, far from rendering floral illustrations redundant, Linnaeus affected significant developments in the art thereof which in turn influenced the making of the earliest Patnakalam paintings.

\section{European Botanical Illustration}

To get a proper sense of the European tradition of floral art and illustration, a brief survey is in order. Flowers in art have a long and varied history in Europe. In Renaissance art from Botticelli to Da Vinci - they are often imbued with great symbolic significance. Flowers continued to appear in religious paintings all through the sixteenth century. But it is to the more mundane and utilitarian world of medicine that we must turn, to find the tradition relevant to our present study. The first printed books describing flowers were intended as visual guides to assist in the identification of plants and herbs for collection for medicinal purposes. These books were called herbals and used woodcuts for illustrations. Herbarum Vivae Eicone published in 1530 by Otto Brunfels in Mainz is an outstanding example of the herbal. The etchings in this book are attributed to a draughtsman named Hans Weiditz. The plants in Brunfels' herbal are notable for their modern realism and scientific accuracy.

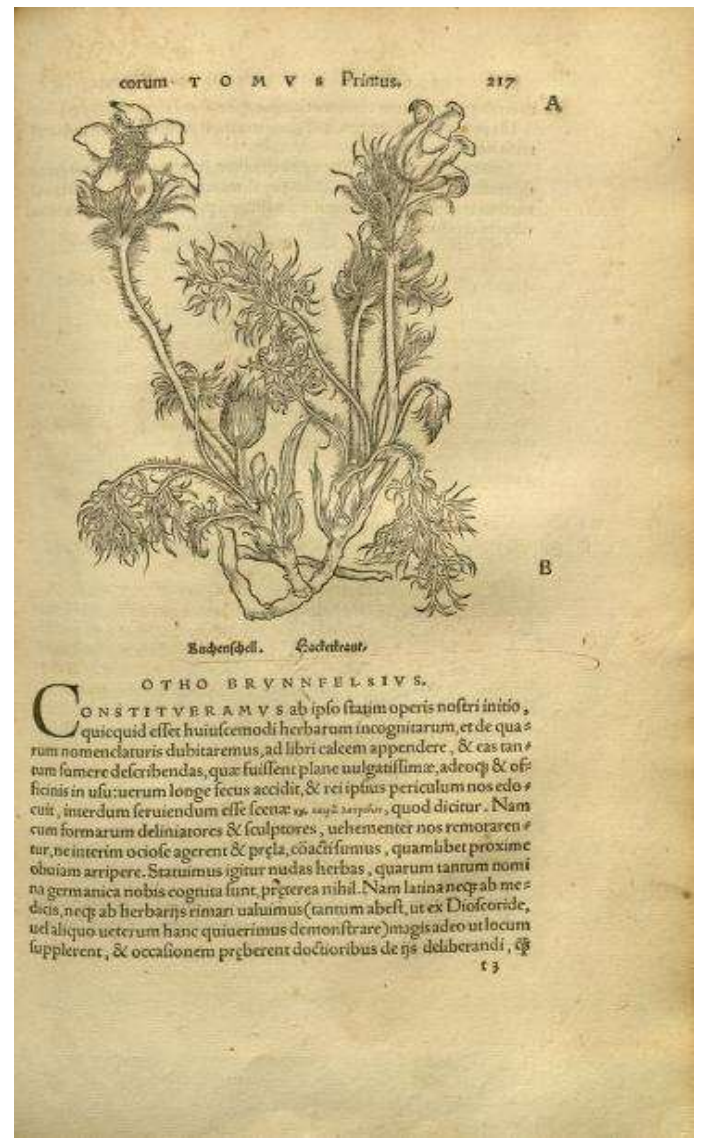

Figure 1. Küchenschelle (Pulsatilla Vulgaris) in Herbarum Vivae Eicones, print 1530 
If Weiditz woodcuts were unfailingly realistic and clinically scientific, those in Fuchs's De Historia Stirpium (1542) were much more artistic. These illustrations were done by Albrecht Meyer. The plants are drawn in thin outlines designed to be hand-coloured. Fuchs's herbal proved to be very popular and many editions appeared after it was published including the German New Kreüterbuch (1543). De Historia Stirpium has a looming presence in the story of the flower illustrations in Europe. The illustrations from this book were copied and used in herbals all over Europe all through the sixteenth and the seventeenth centuries.

A new kind of books of flowers started appearing in the seventeenth century called the florilegium. These contained illustrations of flowers which were grown for ornamental rather than medicinal purposes. A chief sub-category of the florilegium was the garden catalogue, which recorded the various varieties of plants of a patron's garden. Florilegia, both in manuscript and print forms, began appearing all over Europe, particularly Netherlands, France and Germany. Some notable examples are Florilegium by Aedriaen Colaert (Antwerp, 160o), Le jardin du Roy tres chrestien, Henry IV by Pierre Vallet (France, 16o8), Hortus Floridus by Crispin de Passe (Utrecht, 1614), Theatrum Florae by Daniel Rabel (France, 1622) and Fiori Diversi by Nicholas Robert (Rome, 1640). Daniel Rabel and Nicholas Robert also produced detailed flower paintings on vellum cataloguing the botanical garden of Gaston d'Orleans, King Louis XIII's younger brother.

Geographical exploration and colonial expansion led to an interesting development in the production of flower illustrations coming out of the Dutch Golden Age. Various Dutch trading companies established bases and gained administrative control in several coastal territories in South Asia, the Americas and Africa. Scientists and draughtsman travelled to these places and produced natural history drawings including water colours of flowers. Botanist Georg Rumphius's (1628-1702) six-volume Herbarium Amboinense which was published posthumously in 1740 is a compendium of the flora of Ambon Island in Indonesia. A least one of the artists whose drawings on which the illustrations of this book were based was a soldier who had training in draughtsmanship (Blunt, 1994, p. 131).

An important text from the Dutch empire in the seventeenth century is a book commissioned by Hendrick Van Rheede, the Governor of the Dutch colony in Cochin: Hortus Malabaricus. Hortus Malabaricus is a twelve-volume survey of the flora of the Dutch controlled Malabar region of India and published in Amsterdam from 1678 to 1703. It contains more than 700 engravings of plant species along with detailed ethno-medical information about them. Produced at a time when the modern discourses around colonialism were still embryonic, this curious piece of work relied on and acknowledged local informants - one Ezhava practitioner of local medicine (Ayurvedic vaidya) and three Brahmin scholars. The illustrations were based on drawings made by Dutch soldier artists from nature (figure 4). Hortus Malabaricus is a serious scientific treatise. Books like this which purported to accurately record information about exotic flora produced by explorers and colonial scientists, were very important in terms of providing scientific data and greatly contributed to the development of modern Botany in Europe. Carl Linnaeus acknowledged these compendia as important sources of information. He also adopted many of the species named in Hortus Malabaricus in his naming system. The floral illustrations in the book are 
very realistic although several are now difficult to identify. This is so because some of the visual conventions that modern botanical illustration relies on for positive identification had not been invented yet.

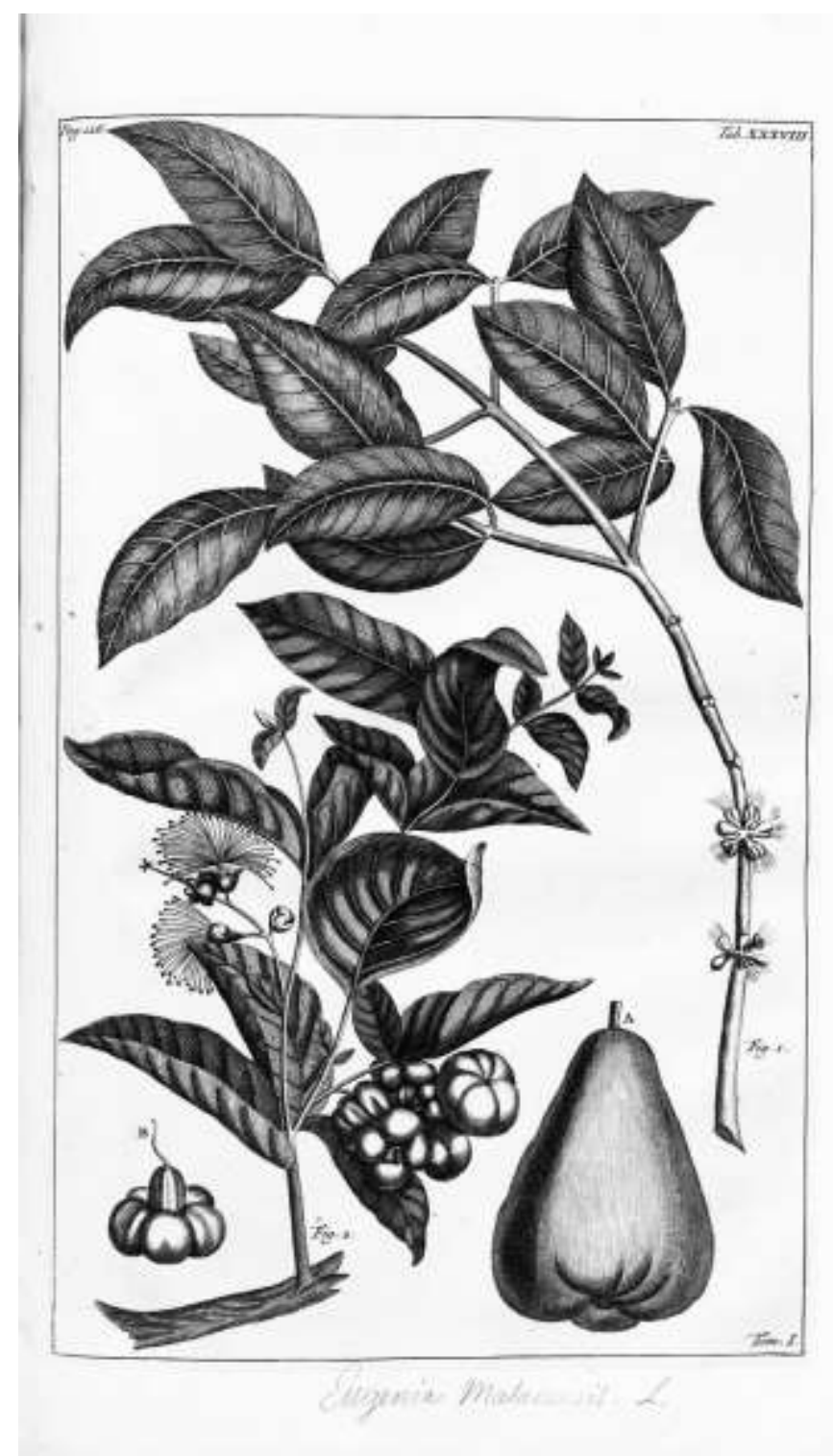

Figure 2. Malay Rose Apple in Herbarium Amboinense, print c. 1680

Explorations within Europe and outside it during the late eighteenth century often led to the production of scores of new Floras or books describing the plants of a defined geographical area. In fact, it was the peak period of such activity as it coincided with increased geographical exploration and the rise of the unifying taxonomic system of Carl Linnaeus. Sir Joseph Banks contributed to many of these through his voyages. 


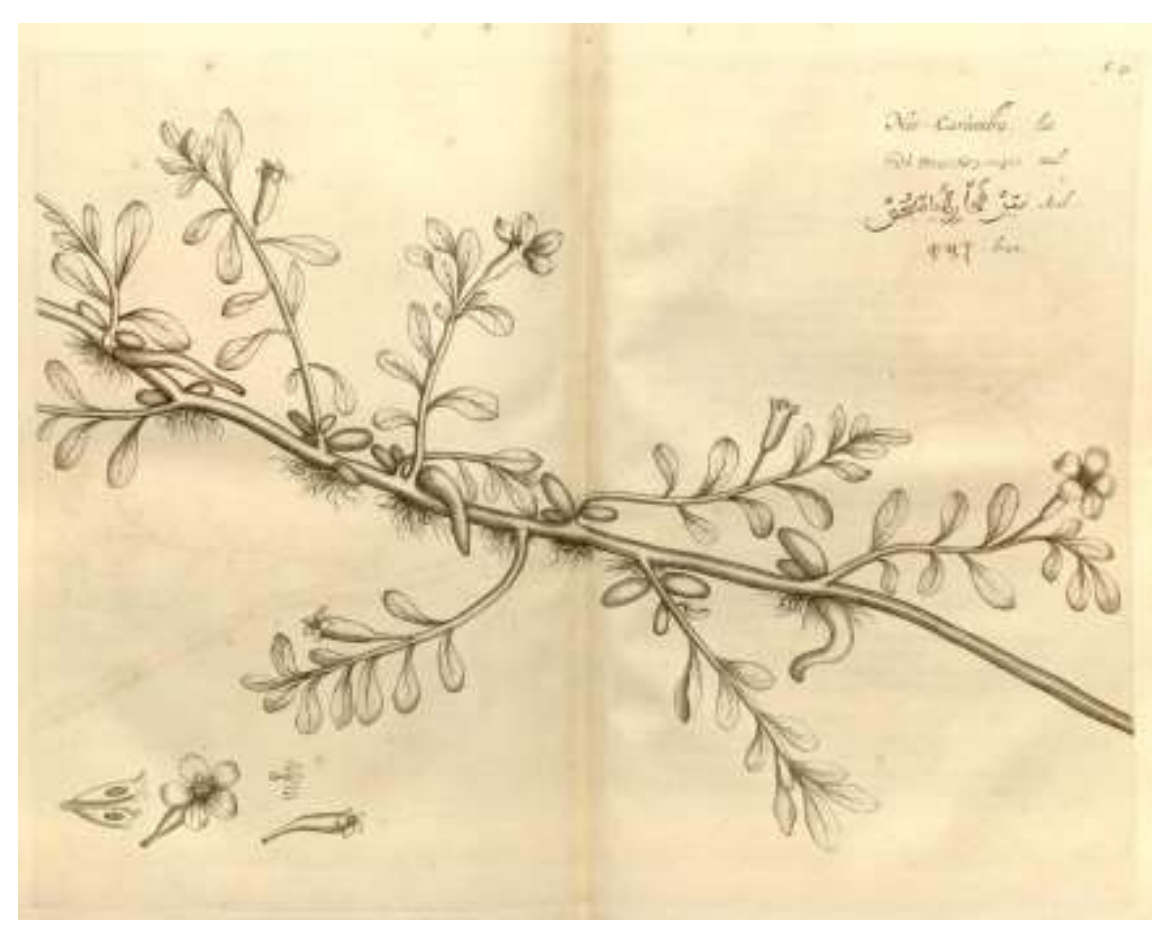

Figure 3. Kumudi flower, Hortus Malabaricus, print c 1678-1703

Georg Dionysius Ehret (1708-1770) played an important role in establishing and perpetuating the unifying visual vocabulary that dominated botanical art and illustration for another century. He collaborated with Carl Linnaeus in 1735 to illustrate his Hortus Cliffortianus. Linnaeus taught Ehret about his taxonomical system, and impressed upon him the importance of depicting the minutest details such as stamens and pistils with accuracy. Ehret illustrated several florilegia and travel books including Trew's Plantae Selectae (1750), Patrick Browne's The Civil and Natural History of Jamaica (1756) and for Alexander Russell's History of Aleppo (1756). He also produced several water colours on vellum. Ehret's flowers inhabit the venn overlap - the intersection - of art and science. His illustrations are scientifically accurate while also displaying an artistic sensibility in their design. Other notable artists from around this period include Sydney Parkinson (1745-1771), John Sibthorp (1758-1796) brothers Francis Bauer (1758-1840) and Ferdinand Bauer (176o1826) Pierre-Joseph Redoute (1759-18-40).

The visual language of the floral illustration of eighteenth century Europe draws from the latest developments in Botany as well as from a long artistic tradition of depiction of artifacts from nature. In it the image is both naturalistic and schematic. Convention of European art such as shading for depth, implied light source, and linear perspective along with the requirement of science, ie, concerned with general properties of the species rather than individual specimen constitutes the vocabulary of the eighteenth century European Flora. It is this that British patrons and employers brought to the Patna artists in late eighteenth century that inaugurated a new hybrid school. 


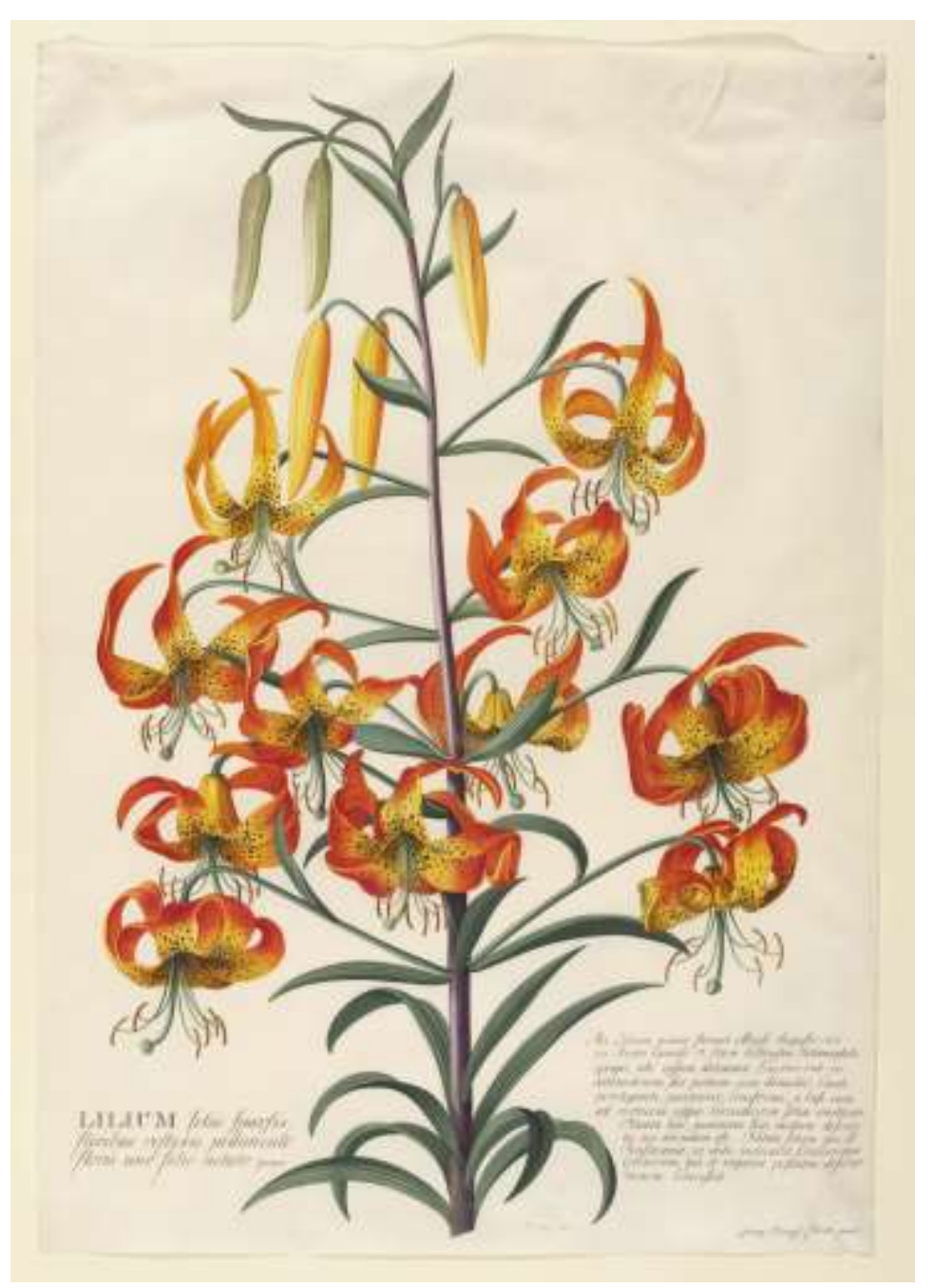

Figure 4. American Turk's Cap Lily, watercolour on vellum, Ehret c174o

\section{Indian floral tradition}

The early Patnakalam painters were trained in the Mughal tradition. The decline of the Mughal ateliers by the middle of the eighteenth century caused the migration of artists to newer centres of power where patronage could be found (Archer, 1947, p. 6). To get a sense of the art that they brought with them we must look at their artistic heritage.

Flowers held a special place in the aesthetic sensibility of the Mughals. Floral motifs were ubiquitous not only in paintings but also in textile, carpets, carvings, metalwork, masonry, and lapidary work. Mughal artist-craftsmen often collaborated outside of their specialty which lent a certain organic flavour to the Mughal artistic corpus. It was during the times of Jahangir (1569-1627) that this passion for flowers reached its high point. They often showed up in all sorts of paintings as part of the composition. More importantly, they were being painted as standalone subjects. Sometimes floral patterns were used in borders, painted gold against a light blue background. This is similar to the border colouring convention of Persian art which was one of the parent traditions of Mughal painting. 
Around the same time, another kind of floral border scheme developed and took hold. This border consisted of loosely organized mini flower studies that were a lot more naturalistic and even identifiable. These were colourful rather than the monochromatically gold. The influence of contemporary European herbals may have given rise to the colourful irises and narcissuses that populate the margins of Shahjahan's albums.

Shahjahan (r. 1628-1658) patronised numerous artists and commissioned many manuscripts, portrait albums and as per tradition an illustrated history. He continued and completed the work started by his father. For instance, the Kevorkian album, named after its last owner who donated it to the Metropolitan Museum, New York, is known to have been started by Jahangir and finished by Shahjahan. The border designs attributable to Shahjahan are naturalistic flowers reminiscent of the botanical studies of the sixteenth century European herbals. Sometimes the flowers are composites but often it is possible to identify the species. For instance, the flowers in the upper border of this image from left to right have been identified as chrysanthemum, rose, lily, iris and Umbellifrae (Swietochowski, 1987, p. 228).

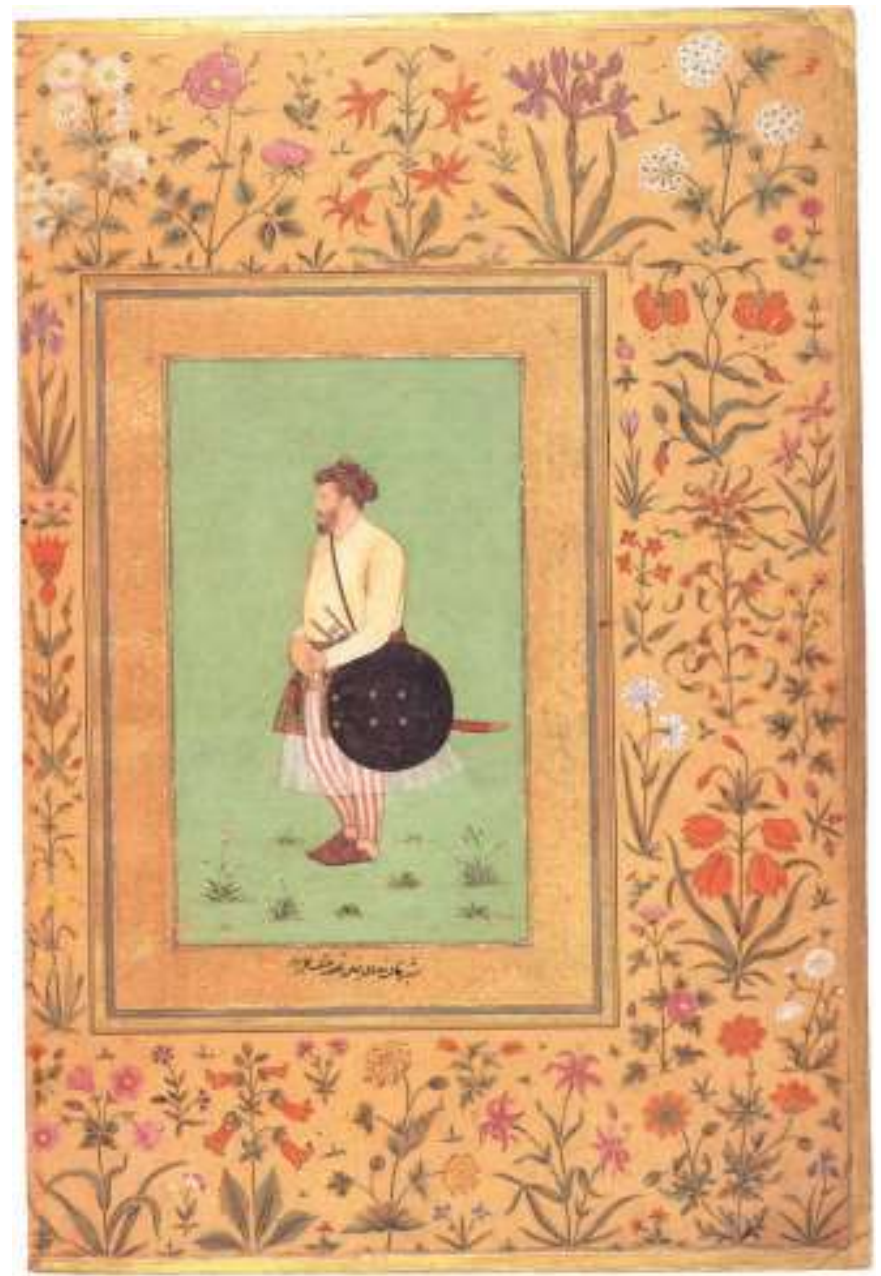

Figure 5. Portrait of Khan-Dauran Bahadur Nusrat-Jang c.164o $\odot$ The Metropolitan Museum, New York

Shahjahan got standalone studies of flowers made as well. The Masters of the Border 
usually took on the task. The painting of flowers on a blank background continued to endure as a legitimate type of painting in the Mughal tradition. Mughal art continue to be practiced under Aurangzeb (r. 1658-1707) though the golden age of royal ateliers was past. By the middle of the eighteenth century, the Mughal capital was no longer the hub of culture. Artists moved away to new centres of culture in the provincial cities like Lucknow, Oudh and Patna (Archer, 1992, p.113). So even though, the Mughal ateliers were slowly being abandoned, Mughal painting continued to be made elsewhere. The last set of images to complete this survey comes from Oudh. The Small Clive album, said to have been given to Lord Clive by the Nawab of Oudh, Shuja ud-Daula in c 1765, contains several paintings of flowers. Some of these are singular studies while others appear in the border. In this painting, one can see a certain kind of simplicity in the idiom that almost belies the splendor of its legacy (figure 6). Nevertheless, the interplay between naturalistic depiction and gentle formalism makes this worthy of its name.

The Patnakalam artists came from the Mughal tradition. When they were employed by their new British masters to make botanical studies, they brought with them a long legacy of art hardwired into their neural pathways. The commingling of what they knew already and what they were newly exposed to marked the beginning of a new hybrid artistic tradition.

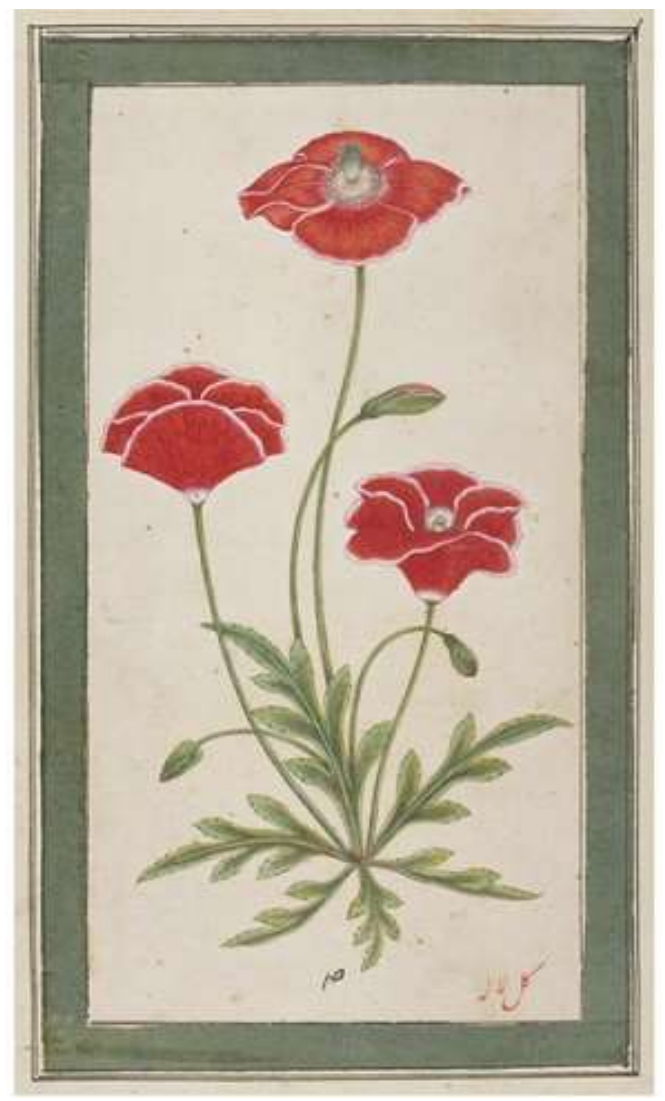

Figure 6. Poppies Oudh c.1765 안 Victoria and Albert Museum, London 


\section{Birth of Patnakalam}

Some of the earliest drawings made for British patrons by Indian artists that are documented as having been made by Patna artists are flowers. Many of these were commissioned as exotic art pieces while others were for purely scientific documentarian use. In addition to these, there are innumerable unsigned paintings in various catalogues which can be attributed to early Patna artists engaged by British civil servants. The employment of these artists in this way steadily for years from as early as 1776 to at least 1815 created an atmosphere conducive to the beginnings of a school of painting in which an indigenous artistic style was shaped and adjusted according to specific European requirements.

Eighteenth century was a time of great political turmoil in India. The Mughal Empire was crumbling and erstwhile subahs were undergoing great administrative changes. In 1704, Prince Azim us Shan, Aurangzeb's grandson, made Patna his seat of administration and renamed it Azimabad. Though Patna never equalled the cultural richness of Lucknow under the nawabs of Oudh, it did become a relatively prosperous and stable urban centre. Its enduring identification with the Mughal court meant there were "opportunities for building a regional cultural tradition which derived its legitimacy through the conscious patronage of poets, painters and men of letters who had fled from Delhi" (Chatterjee, 1996, p. 19). By the 1750s, many artists had migrated to Patna.

Lady Mary Impey was the wife of Lord Elijah Empey (1732-1809) who was the first Chief Justice of the Supreme Court at Fort William set up in 1774. The Impeys maintained a private menagerie and garden in Calcutta to house the indigenous flora and fauna. They employed three Patna artists - Shaikh Zayn al Din, Bhawani Das and Ram Das - to depict their collection. The project begun in 1777 resulted in more than 300 paintings of birds, animals, insects and plants. The paintings are considerably larger than the miniatures of the Mughal School. They are done in watercolour on paper and depict the subject against a blank background.

An even earlier instance of drawings done by Patna artists for a British employer is a collection of botanical illustrations made for James Kerr (1738-1782). ${ }^{1}$ Unlike the ones commissioned by Lady Impey, these paintings were documentary rather than ornamental. James Kerr was a Scottish Surgeon on the Bengal Establishment from 1770 to 1782 and served in Bengal and Bihar. Kerr's botanical drawings are meant to be scientific illustration, made with a view to identify and describe the plants for possible medicinal or commercial use. There are two known collections of Kerr's plant drawings. The first is a set of three volumes containing 559 water colour drawings of plants and at one point in time were owned by explorer Sir Joseph Banks. The second folio contains drawings of 101 species all of which are copies of paining from the first collection. According to H G Noltie, Kerr employed more than one artist some of whom were likely from Patna (2017, p. 23). The Kerr illustrations use a relatively bright colour scheme. At their finest, they show the same lyrical delicacy as Mughal florals (figures 7 and 8). In many cases however, the style suffers as the lines are rigid as though deliberately warned off pattern-like design but without the benefit of being given an alternative visual guide to follow. The influence of European Botany is 
clear in the care shown in drawing leaf nodes, pistils and stamens. In some of illustrations the reproductive parts of the flower are depicted separately in line with European Botanical illustration practice.

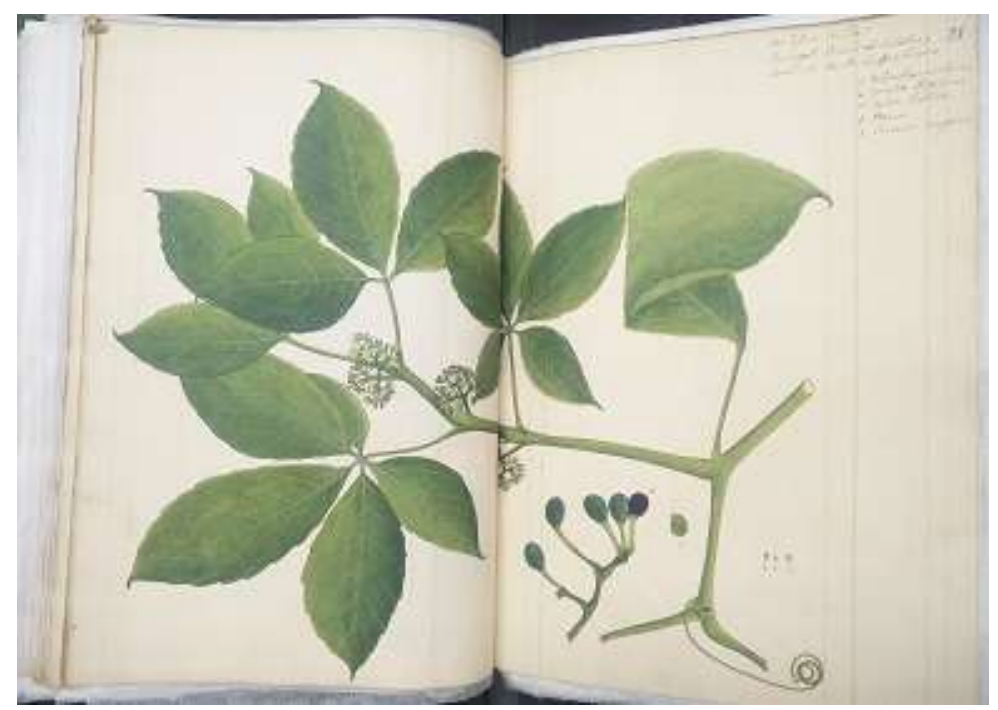

Figure 7. Kerr Album, c.1780 @ Natural History Museum Library, London

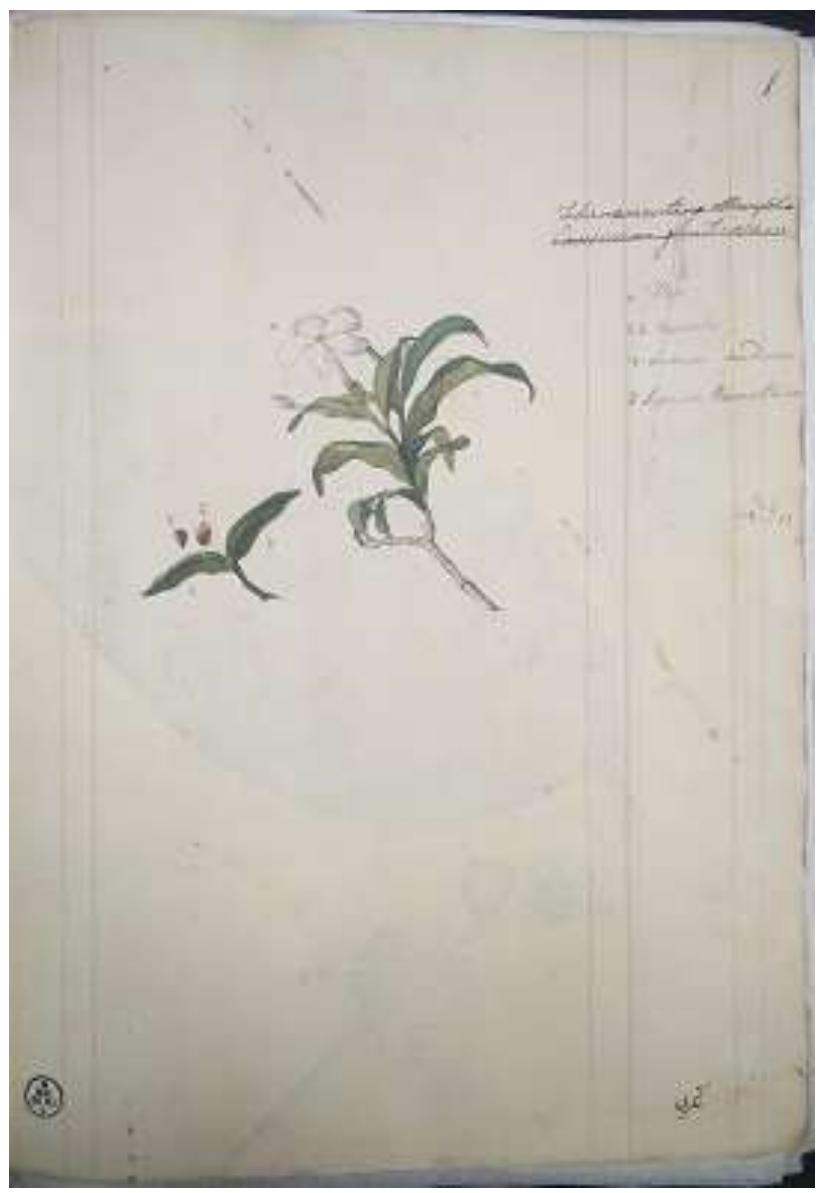

Figure 8. Kerr Album, c.1780 @ Natural History Museum Library, London 
Richard Parry who served in the Company Treasury in various capacities from 1796 to 1803 , travelled to Sumatra in 1807 where he remained till 1811 as Resident. He brought Patna artist Manu Lal with him to Sumatra who made about 200 natural history drawings of birds, animals and plants for him. Manu Lal along with many other Indian artists from various places within Company Raj also worked for Marquis Wellesley (1760-1842) for his personal collection. ${ }^{2}$

The catalogues of Kerr and Parry are prime examples of the spirit of scientific enquiry brought on by Enlightenment put to work to further the colonial project. The intellectual legacy of the European Enlightenment manifested in Colonial spaces in late eighteenth and early nineteenth century in the form of official missions to document, name and systematize the sociological, cultural, topographical and other kinds of knowledge about places like India. In case of natural history, the Company encouraged its officials to pursue their interest in Natural History. In 1782, the East India Company appointed Gerhard König (1728-1785) a pupil of Carl Linnaeus as official Botanist. König got many illustrations done for his collection. He was the first to apply the Linnaean classification on Indian plants. William Roxburgh (1751-1815) who succeeded him carried forward this enterprise. For over twenty years, Roxburgh employed local artists to produce illustrations to supplement his written plant description. There is not enough documentation available to ascertain the identity of all the Indian artists thus employed by the British. However, given the precedence of movement of Patna artists to Calcutta for employment, there is no reason to doubt that many artists from Patna worked on these catalogues.

Apart from Kerr and Roxburgh catalogues, there are numerous botanical illustrations of unknown commissions which exist in various collections. An intriguing set of drawings in the Kew Garden Library, London bear names of artists as well as the date of their commission although it is uncertain who commissioned them and whether they were part of an amateur private collection or meant for an official catalogue. These provide a glimpse into the early period of Patnakalam. The artists, Chunni Lal, Brij Lal and Pyare Lal (spelt Bearilall in the drawings) whose names seem to have been added later in English, may have been part of the corpus of indigenous artists routinely engaged by British officials. These paintings are characterized by a thin ink outline, which is filled in with gouache watercolour. The composition in each of these displays a tendency towards symmetry and pattern. The elements of the composition - flowers, leaves - are laid flat against the background, recalling the floral borders of seventeenth century Mughal paintings. However, these drawings are documentary rather than decorative. The style of these three painters is not very distinguishable from each other. As is typical in botanical illustrations from the Raj, there are no borders. Since there is no scale provided, an early convention in Botanical illustrations was to cover the entire page with the drawing to denote largeness. This is seen in the illustration for Pterospermum Diversifolium, a tree which grows up to 20 meters in height, where the leaves are barely contained by the sheet (figure 10).

Remarkably, these botanical illustrations contain the names of their painters. These names provide an important clue about the development of Patnakalam. They all have the same surname - Lal, variously spelt Lall - which is a historically recognisable Kayasth name from Bihar. The majority of Patna painters were from the Kayasth caste. As the school 
developed through the nineteenth century many artists who descended from this clan like Shiva Lal, Shiva Dayal Lal, Gopal Lal, Guru Sahay Lal, Bani Lal, Girdhari Lal and Bahadur Lal helped shape its course. From among these early botanical painters, Pyare Lal's career is indicative of the general trajectory of the Raj's illustrators from making scientific sketches to popular art later on. Apart from working on this commission, he also worked as a copyist in the Surveyer General Colin Mackienzie's (1754-1821) office. In that role he sketched copies of archaeological ruins, historical monuments and so on from drawings. He went on to become a bazaar painter in Patna in the 1820s. He is known to have painted so-called firka sets, or sets of paintings depicting various occupations, scenes of everyday life, festivals, modes of transport and so on. These were very popular and often bought as souvenirs. He is a representative figure in the transition of Patnakalam from the government offices to the market.

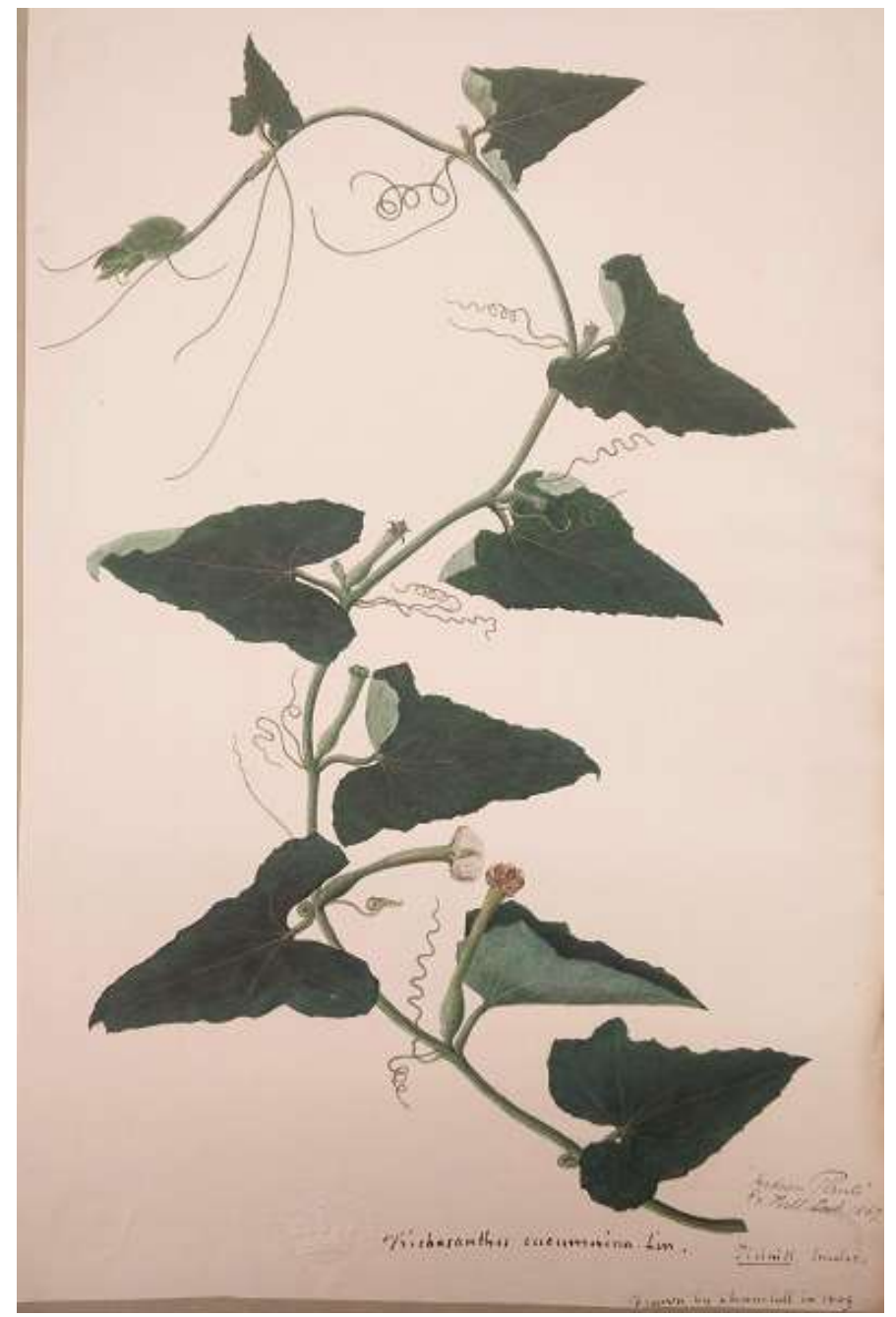

Figure 9. Chunni Lal, Trichosanthes Cucumerina, 14inx9in, 1809, (C) Kew Archive, London 
15 | Indian Art and European Science: Patnakalam and Colonial Botanical Drawings

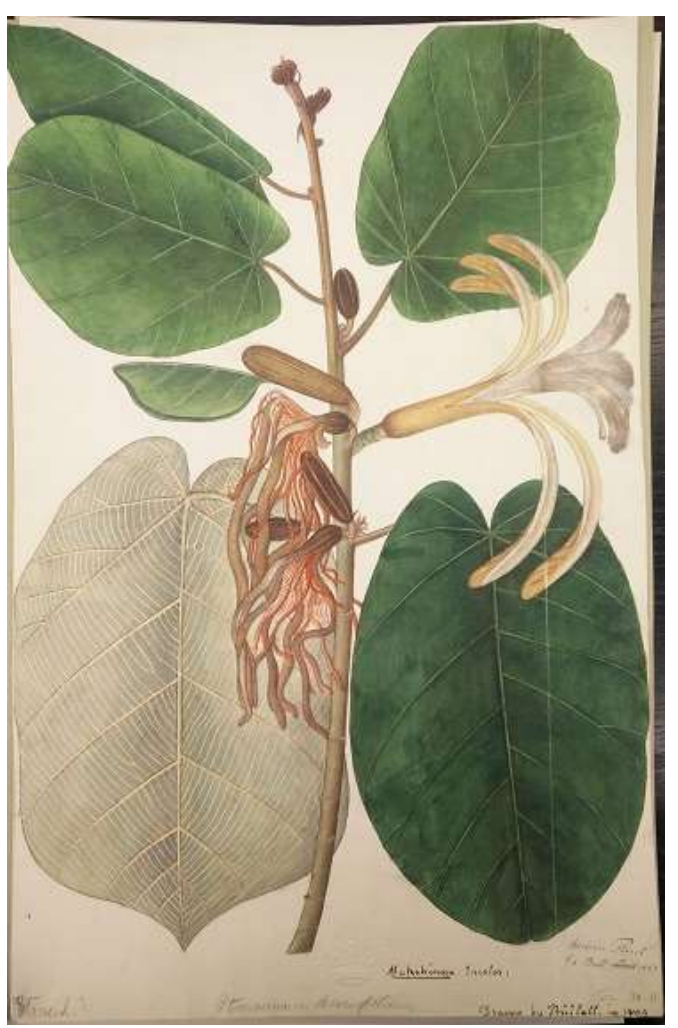

Figure 1o. Brij Lal, Pterospermum Diversifolium, 14 in x 8 in, 1809, ( $)$ Kew Archive, London

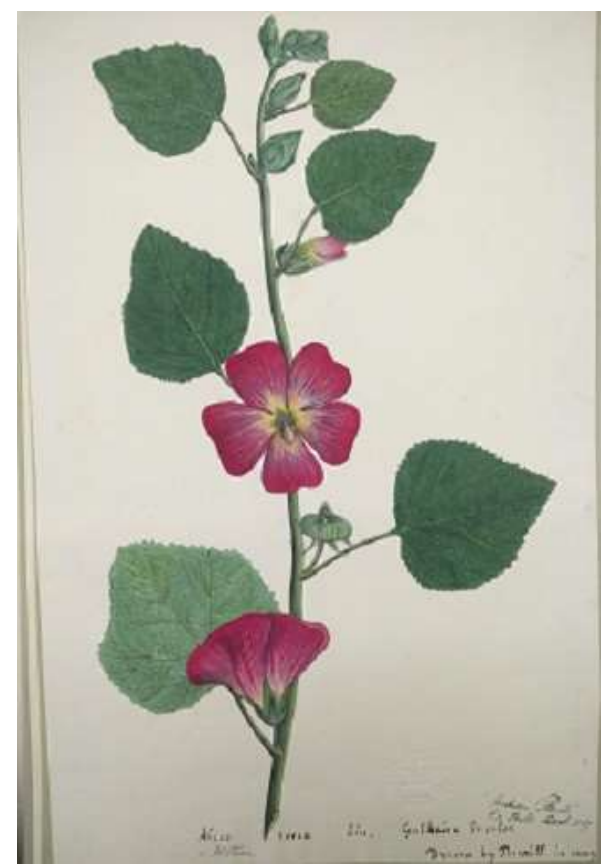

Figure 11. Pyare Lal, Alcea Rosea, 14 in x 8.5 in, $1809 \Subset$ Kew Archive, London 


\section{Conclusion}

The employment of Indian artists from Patna by British Botanists in the late eighteenth and early nineteenth centuries was a crucial step in the formation of the idiom of Patnakalam. The mixing of Mughal training with a European sensibility produced drawings which were accurate while also being "exotic". Even though these Botanical drawings were meant for a specialist audience, they helped create space for a contemporary hybrid style. The courtly Mughal style was transformed as the artist negotiated his place in the new regime of power. Over the course of the next few decades after this transformation, the Patnakalam artist considerably expanded his subject matter, established his style and broadened his clientele. By the middle of the nineteenth century, Patnakalam had moved far beyond its natural history roots and become a popular school with myriad other European influences and set schema and subjects. Many artists like Pyare Lal, who had previously worked for British commissioners, transitioned to making souvenir paintings for the market. These paintings had a steady demand all through the nineteenth century. Patnakalam, which had emerged as a supplement to the colonial documentarian project went on to become one of the most enduring symbols of the colonial encounter.

\section{Endnotes}

${ }^{1}$ See Mildred Archer, Natural History Drawings in the India Office Library (London, H M Stationer's Office, 1962) for a catalogue of taxonomical and scientific illustrations commissioned by British officers all over the Indian subcontinent. Though comprehensive, this account gives scant information about individual artists and schools, centering the narrative on the British colonial project instead.

${ }^{2}$ Manu Lal is among the very few eighteenth century Indian illustrators to be included in the Database of Scientific Illustrators 1450-1950, University of Stuttgart.

\section{References}

Archer, Mildred. (1947). Patna Painting. London: Royal India Society.

Archer, Mildred. (1992). Company Paintings: Indian Paintings of the British Period. London: Victoria and Albert Museum, India Art Series.

Archer, Mildred. (1962). Natural History Drawings in the India Office Library. London: HM Stationer's Office.

Blunt, Wilfrid, and William T. Stearn. (1994). The Art of Botanical Illustration. Woodbridge, Suffolk: Antique Collectors' Club in association with the Royal Botanic Gardens, Kew.

Chatterjee, Kumkum. (1996). Merchants, Politics, and Society in Early Modern India: Bihar, 1733-1820. New York: E.J. Brill

Kant, Immanuel, and Mary J Gregor. (1999). Practical Philosophy. 1st ed. Cambridge: Cambridge University Press. pp. 17-21.

Noltie, Henry J. (2017). Botanical art from India: The Royal Botanic Garden Edinburgh Collection. Edinburgh: Royal Botanic Garden Edinburgh.

Stafleu, Frans A. (1971). Linnaeus and the Linnaeans. The Spreading of their Ideas in Systematic Botany, 17351789. Utrecht: Oosthoek.

Hankins, Thomas L. (1985). Science and the Enlightenment. New York: Cambridge University Press. 
17 | Indian Art and European Science: Patnakalam and Colonial Botanical Drawings

Linné, Carl and Stephen Freer. Linnaeus' Philosophia Botanica, Oxford: Oxford University Press, 2003.

Nickelsen, Kärin. (2006). Draughtsmen, Botanists And Nature: The Construction of Eighteenth-Century Botanical Illustrations. Dordrecht: Springer.

Welch, Stuart C., Annemarie Schimmel, and Marie L. Swietochowski. (1987). The Emperors' Album: Images of Mughal India [catalog of an exhibition held at the Metropolitan Museum of Art from October 211987 to February 14 1987]. New York: Metropolitan Museum of Art. 